UDC. 504.5:669.017:631.95

Petro G. Kyrienko, PhD, docent of the Department of chemistry, ecology and expert technologies

e-mail: p.kirienko@khai.edu

Tetyana O. Klocko, senior lecturer of the Department of chemistry, ecology and expert technologies

e-mail: t.klocko@khai.edu

Irina Y. Khomenko, senior engineer of the Department of chemistry, ecology and expert technologies

e-mail: khomenko.19.10@gmail.com

Ganna M. Durnevich, student of the Department of chemistry, ecology and expert technologies

e-mail: anna.durnevich.99@gmail.com

National Aerospace University "Kharkiv Aviation Institute”, Kharkiv, Ukraine

\title{
ANALYSIS OF HEAVY METAL MIGRATION IN VEGETABLE AGRICULTURAL WASTE
}

\begin{abstract}
One of the most important tasks facing Ukraine is to maximize the use of its own renewable energy resources, including the use of agricultural waste (stems, straw, sunflower husks, bonfires, etc.) to obtain energy sources such as fuel briquettes and pellets. The urgency of complete utilization of agricultural waste depends on the content of heavy metals in the ash formed during the combustion of fuel briquettes made from agricultural waste. The entry of heavy metals from the soil into plants today is a serious environmental problem, as a result of which human and animal food, as well as agricultural waste are contaminated with heavy metals. After making briquettes or pellets, they can be used as fuel in various installations. When briquettes or pellets is burning made from agricultural waste, ash is formed, which can be used as an additive to organic fertilizers, while heavy metals at high temperatures can form oxides and then salts, which are less susceptible to migration into plants. The analysis of migration of heavy metals from soil to plants is carried out. The possibility of using vegetable waste to obtain fuel briquettes and pellets is considered. The comparison of the content of heavy metals in the plant with the maximum permissible concentration was checked. The content of harmful substances in the ash was determined after their use. The scheme of technological sequence of production of briquettes and pellets from vegetable waste is presented. The possibility of using pellet ash and briquettes as additives to organic fertilizers is analyzed. In general, the processing of vegetable waste into fuel briquettes and pellets is a very effective environmental solution that allows the maximum use of agricultural waste as a renewable energy resource, as well as to bind heavy metals and prevent their further migration.
\end{abstract}

Keywords: heavy metals; migration; vegetable waste; fuel briquettes; fuel pellets

(C) П.Г. Кирієнко, Т.О. Клочко, І.Є. Хоменко, Г.М. Дурневич, 2020 


\title{
П.Г. Кирієнко, Т.О. Клочко, І.Є. Хоменко, Г.М. Дурневич
}

Національний аерокосмічний університет ім. М.Є. Жуковського «Харківський авіаційний інститут», м. Харків, Україна

\section{ДОСЛІДЖЕННЯ МІГРАЦІЇ ВАЖКИХ МЕТАЛІВ У РОСЛИННИХ ВІДХОДАХ СІЛЬСЬКОГО ГОСПОДАРСТВА}

\begin{abstract}
Анотація. Одне з найважливіших завдань, які стоять перед Украӥною, полягає в максимальному використанні власних відновлюваних енергетичних ресурсів, зокрема використанні відходів сільського господарства (стебла, солома, лушпиння соняшнику, костриия та ін.) для виготовлення паливних брикетів та пелет. Актуальність повної утилізаиії відходів сільського господарства залежить від вмісту важких металів в попелі, що утворюється при спалюванні паливних брикетів, виготовлених з відходів сільського господарства. Надходження важких металів з трунту в рослини на сьогоднішній день є серйозною екологічною проблемою, внаслідок якої продукти харчування людини та тварин, а також відходи сільського господарства забруднюються важкими металами. Після виготовлення брикетів або пелет їх в подальшому можна використовувати як паливо в різних установках. При спалюванні брикетів або пелет, виготовлених із відходів сільського господарства, утворюється попіл, щчо може використовуватись в якості добавки до органічних добрив, при иьому важкі метали при високих температурах можуть утворювати окисли, а потім $i$ солі, які менше піддаються міграції в рослини. Проведено аналіз міграції важких металів з трунту в рослини. Розглянуто можливість використання рослинних відходів для отримання паливних брикетів та пелет. Перевірено відповідність вмісту важких металів у рослині з гранично допустимою концентрацією. Визначено вміст шкідливих речовин $y$ золі, після $\ddot{x}$ використання. Представлено схему технологічної послідовності виробництва брикетів та пелет з рослинних відходів. Проаналізовано можливість використання попелу пелет та брикетів в якості добавок до органічних добрив. В иілому переробка рослинних відходів в паливні брикети та пелети є досить ефективним екологічним ріменням, щзо дає змогу максимально використати відходи сільського господарства як відновлюваний енергетичний ресурс, а також зв'язати важкі метали та запобігти їх подальшій міграції.
\end{abstract}

Ключові слова: важкі метали; міграџія; рослинні відходи; паливні брикети; паливні пелети

\section{Вступ}

Одне 3 найважливіших завдань, які стоять перед Україною, полягає в максимальному використанні власних відновлюваних енергетичних ресурсів, зокрема використанні відходів сільського господарства (стебла, солома, лушпиння соняшнику, костриця та ін.) для виготовлення паливних брикетів та пелет. За «Національним планом дій з відновлюваної енергетики на період до 2020 року», Розпорядженням КМУ від 01.10.2014 № 902-р, споживання енергії, виробленої з відновлюваних джерел, має становити 8,59 млн т.н.е., що складе $11 \%$ від сукупного кінцевого споживання енергоресурсу. Відновлювані джерела енергії (ВДЕ) відіграють помітну роль в економіці України. Станом на кінець першого півріччя 2019 р. встановлена потужність об'єктів 
відновлюваних джерел енергії досягла 3634,4 МВт, у тому числі СЕС - 2640,4 МВт (сонячні електростанціі), ВЕС - 776,6 МВт (вітрові електростанціi), установок на біомасі - 51,3 МВт, біогазі - 66,4 МВт.

\section{Основна частина}

Для оцінки ступеня забруднення відповідно до класифікації хімічних речовин для контролю грунтів взято важкі метали усіх трьох класів небезпеки: I клас дуже небезпечні (Cd, Pb, Zn), II клас - помірно небезпечні ( $\mathrm{Cr}, \mathrm{Ni}, \mathrm{Cu}, \mathrm{Co}$ ), III клас - мало небезпечні - (Mn, Fe). Форми міграції важких металів в грунтах вивчені недостатньо. Переважна частка орних земель країни певною мірою забруднені важкими металами, основними з яких є $\mathrm{Ni}, \mathrm{Zn}, \mathrm{Cd}, \mathrm{Pb}, \mathrm{Hg}$ і $\mathrm{Cu}$.

В процесі росту і розвитку хімічні елементи накопичуються в рослинах і організмах. Біологічна акумуляція сприяє вилученню хімічних елементів рослинами та організмами 3 грунту, тривалість якого відповідає тривалості життя організму. Мікроелементи потрапляють до грунту разом 3 добривом, а також через антропогенні забруднення від промислових підприємств та автотранспортних викидів. Сучасна агротехніка передбачає широке використання мінеральних добрив. Одними із найпоширеніших видів мінеральних добрив є фосфорно-калійні добрива [4]. Всі калійні добрива добре розчиняються у воді. При внесенні в грунт вони дуже швидко розчиняються завдяки грунтовій волозі. Калій споживається грунтовими колоїдами, що зменшує його рухомість, однак він залишається досяжним для живлення рослин. Внаслідок такої фіксації калію його доступність для рослин значно знижується, а іноді він стає зовсім недоступним.

Процеси висушування та зволоження грунту значно посилюють процес фіксації калію. В таблиці 1 наведено приклади культур, які підживлюють калійними добривами, та ефекти впливу калію на їх ріст, розвиток та урожайність [4].

Таблиця 1 - Культури, які підживлюють калійними добривами

\begin{tabular}{|c|l|}
\hline Культура & \multicolumn{1}{|c|}{ Вплив калію } \\
\hline Ріпак & $\begin{array}{l}\text { Ріпак належить до калієлюбних рослин. Калій підвищує стійкість } \\
\text { ріпаку до вилягання, ураження хворобами, зимостійкість, збільшує } \\
\text { кількість насіння в рослині і масу 1000 насінин. }\end{array}$ \\
\hline Соняшник & $\begin{array}{l}\text { Калій бере участь у вуглеводному обміні, транспорті води та } \\
\text { безпосередній оводненості клітин. Також підвищує посухостійкість } \\
\text { соняшнику, допомагає утримати вологу і зменшує їі випаровування. }\end{array}$ \\
\hline Соя & $\begin{array}{l}\text { До початку цвітіння соя засвоює калію в 1,5 раза більше, ніж азоту, і } \\
\text { в 1,8 раза більше, ніж фосфору. Однак найбільше цього елементу соя } \\
\text { споживає в період формування бобів та наливання зерна. }\end{array}$ \\
\hline $\begin{array}{c}\text { Цукровий } \\
\text { буряк }\end{array}$ & $\begin{array}{l}\text { В зв'язку з накопичуванням значної кількості вуглеводів, цукровий } \\
\text { буряк потребує великої кількості калію. Вирощування цукрового } \\
\text { буряку з достатнім внесенням калійних добрив також забезпечує } \\
\text { стійкість рослин до захворювань. }\end{array}$ \\
\hline
\end{tabular}

Завдяки калію вуглеводи із вегетативних органів пшениці переміщуються до колоса, що призводить до якісного наливання зерна, в результаті чого підвищується величина, наповненість зерна клітковиною та вміст білку. Калій 
також має позитивний вплив на кукурудзу. Добра забезпеченість грунту калієм сприяє ефективному використанню вологи, підвищує стійкість до посухи, покращує засвоєння рослиною азоту. Без калію рослина не в змозі перетворювати аміак, в результаті аміак накопичується в рослині, що чинить токсичний вплив на неї [4]. Дефіцит цього елементу на початкових етапах розвитку призводить до зупинки поділу клітин та збільшення вегетативної маси. Калій максимально засвоюється в період інтенсивного росту та наростання вегетативної маси.

Фосфорні мінеральні добрива необхідні перш за все для розвитку кореневої системи рослин. Крім цього, даний елемент регулює їхнє дихання і наповнює рослинний організм енергією. Найбільше фосфору міститься в репродуктивних органах рослин (зерно), які виносяться з поля.

\section{Міграція важких металів}

Рухливість важких металів в грунті і їх надходження в рослини дуже мінливі і залежать від багатьох факторів: виду культури, грунтових і кліматичних умов.

Актуальність повної утилізації відходів сільського господарства залежить від вмісту важких металів в попелі, при спалюванні паливних брикетів, виготовлених з відходів сільського господарства.

Концентрація важких металів залежить від віку рослин. Важкі метали можуть надходити в рослини некореневим шляхом, наприклад, з повітряних потоків, адже на практиці широко застосовуються оприскування рослин мікроелементами. Поглинені листям метали можуть переноситись і в інші рослинні тканини, зокрема в коріння, де можуть знаходитися тривалий час у формі запасу [5].

Основними джерелами антропогенного надходження важких металів в природне середовище $\epsilon$ підприємства промисловості: теплові електростанції, металургійні заводи і транспорт. Технологічні процеси підприємств чорної і кольорової металургії не забезпечені надійними засобами очищення газових викидів, що призводить до сильного забруднення атмосфери навколо цих підприємств. Особливе місце серед забруднювачів займають важкі метали, такі як $\mathrm{Zn}, \mathrm{Cu}$, Co та $\mathrm{Ni}$.

Якщо недалеко від поля, де будуть збирати сировину для виготовлення паливних брикетів та пелет, буде знаходитися підприємство кольорової металургії, виробництво пергаментного паперу або мінеральних фарб, то перераховані вище метали можуть потрапляти в грунт через викиди підприємств у повітря, а потім разом 3 дощем осісти на грунт. Забруднена атмосфера в цьому випадку є головним джерелом накопичення важких металів в грунті і рослинах.

На основі даних (табл. 2) Інституту сільського господарства степової зони НААН України проаналізовано вміст мікроелементів в побічній продукції сільськогосподарських культур.

На основі даних ТОВ «СВНЦ Інтелект сервіс» (табл. 3) проаналізовано та побудовано діаграми вмісту важких металів в сухій речовині кукурудзи, вирощеної на агроугіддях поблизу промислового майданчика, у порівнянні 3 ГДК. 
Таблиця 2 - Вміст мікроелементів в побічній продукції сільськогосподарських культур (мг/кг)

\begin{tabular}{|c|c|c|c|c|}
\hline Культура & $\mathrm{Zn}$ & $\mathrm{Cu}$ & $\mathrm{Co}$ & $\mathrm{Ni}$ \\
\hline $\begin{array}{c}\text { Пшениця } \\
\text { озима }\end{array}$ & $\frac{2,28}{0,65-6,72}$ & $\frac{0,93}{0,15-3,26}$ & $\frac{0,35}{0,14-0,68}$ & $\frac{1,02}{0,30-2,82}$ \\
\hline Ячмінь ярий & $\frac{5,17}{1,17-10,0}$ & $\frac{1,61}{0,30-5,55}$ & $\frac{0,65}{0,17-1,56}$ & $\frac{1,42}{0,50-3,93}$ \\
\hline Кукурудза & $\frac{12,4}{3,69-36,5}$ & $\frac{3,52}{1,02-10,6}$ & $\frac{0,79}{0,30-1,66}$ & $\frac{1,46}{0,64-3,88}$ \\
\hline Соняшник & $\frac{13,2}{5,29-23,6}$ & $\frac{5,12}{2,22-16,7}$ & $\frac{1,45}{0,47-3,22}$ & $\frac{2,63}{0,55-5,51}$ \\
\hline
\end{tabular}

Чисельник - середні значення, знаменник - коливання вмісту (min-тах).

Таблиця 3 - Вміст хімічних елементів у сухій речовині кукурудзи (мг/кг)

\begin{tabular}{|c|c|c|c|c|c|}
\hline \multirow{4}{*}{ 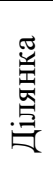 } & \multirow{2}{*}{ Тип проби } & \multicolumn{4}{|c|}{ Важкі метали } \\
\hline & & $\mathrm{Cd}$ & $\mathrm{Cu}$ & $\mathrm{Zn}$ & $\mathrm{Pb}$ \\
\hline & качани & 0,206 & 1,62 & 5,15 & 0,258 \\
\hline & листя & 0,715 & 4,51 & 45,05 & 8,582 \\
\hline
\end{tabular}

Проаналізовані дані (рис. 1 та 2) показують, що рівень вмісту свинцю в листі кукурудзи значно більший, ніж гранично допустима концентрація, тому потрібно мінімізувати використання зеленої маси.

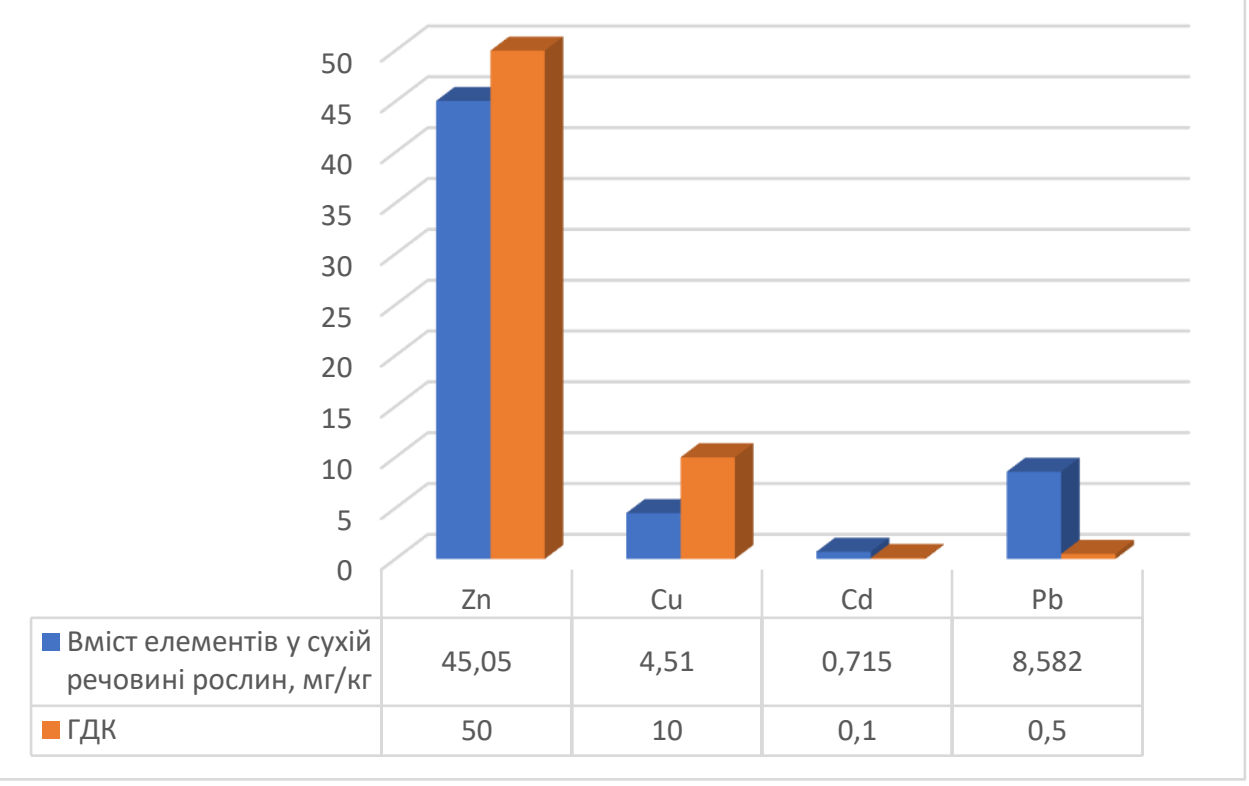

Рис. 1 - Діаграма вмісту важких металів в листі кукурудзи 


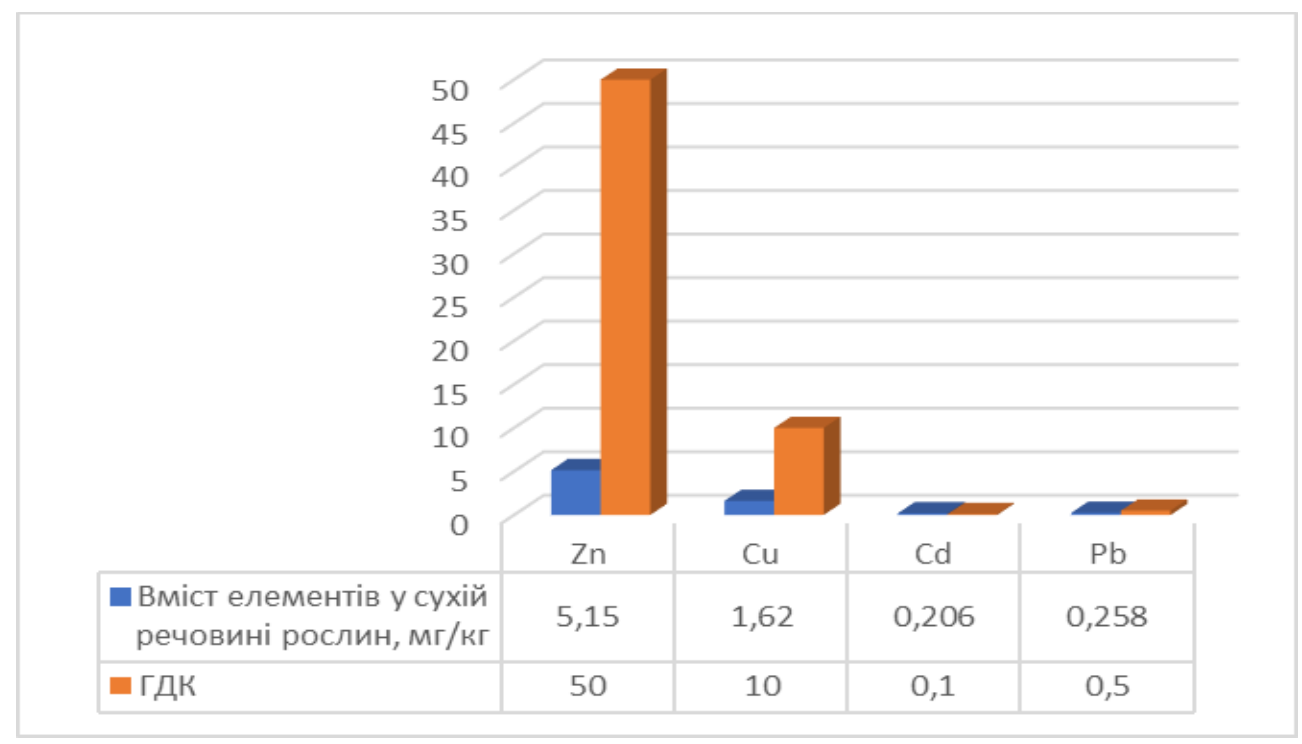

Рис. 2 - Діаграма вмісту важких металів в качанах кукурудзи

Для виготовлення пелет та брикетів широко використовуються рослинні рештки. Весь процес виробництва умовно можна розділити на кілька етапів. Більш детально технологічну послідовність виготовлення брикетів та пелет 3 рослинних відходів зображено на рис. 3 [1].

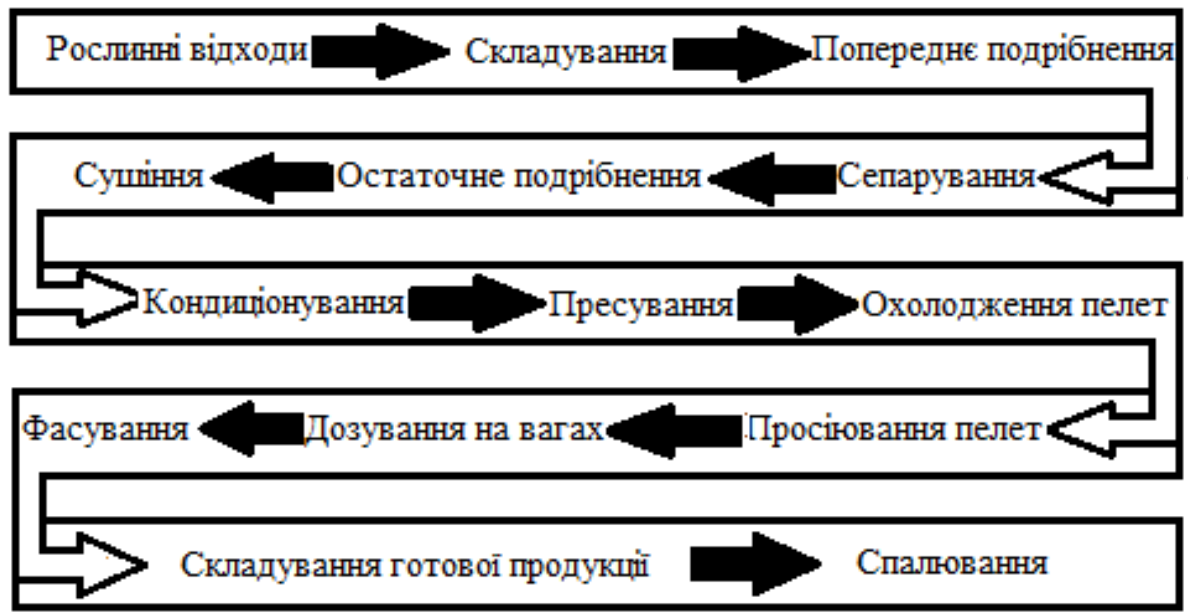

Рис. 3 - Схема виробництва паливних пелет з відходів сільського господарства

Подрібнення, або фракційний склад відходів для пресування, має становити від одного до трьох міліметрів. Для висушування подрібненої сировини економічно доцільно використовувати вакуумні пристрої. Вологість сировини для паливного брикету повинна становити 10-12\%. Процес пресування необхідно проводити на спеціальному обладнанні [3], за двостадійною схемою. Перша стадія відбувається на невеликих швидкостях виконавчих механізмів до $1 \mathrm{~m} / \mathrm{c}$. При цьому відбувається ущільнення 
пресувальної суміші за рахунок пустот між часточками і часткової деформації самих часточок. На цій стадії може виникнути міжмолекулярне зчеплення. Друга стадія - імпульсне стискання. На цій стадії відбувається перехід пружних деформацій в пластичні, внаслідок чого структура брикету вирівнюється, відділяється природний лігнін і деякі смоли, які полімеризуються всередині i на поверхні брикету. Внаслідок швидкого стискання виділяється тепло, яке сприяє полімеризації лігніну i смол. Двостадійний спосіб одержання паливних брикетів має ряд переваг: зменшення енергетичних витрат; не використовуються в'яжучі хімічні добавки; брикети мають високу щільність 1,1-1,4 т/куб. м; теплотворну здатність до 4,4 ккал/кг; залишок попелу не перевищує 3\% [1].

Слід зазначити, що при сушінні подрібненого матеріалу важкі метали залишаються в сировині. Після виготовлення брикетів або пелет їх відправляють на склад, де в подальшому можуть використовувати як паливо в різних установках. При спалюванні брикетів або пелет, виготовлених із відходів сільського господарства, утворюється зола, яка може використовуватись в якості добавки до органічних добрив, при цьому важкі метали при високих температурах можуть утворювати окисли, а потім і солі, які менше піддаються міграції в рослини.

Вуглець, кисень, водень і азот називають органогенними елементами, оскільки 3 них складаються органічні речовини, які формують близько 95\% маси сухої речовини рослин. Вони надходять в рослини переважно у вигляді $\mathrm{CO}_{2}, \mathrm{O}_{2}$ i $\mathrm{H}_{2} 0$. Решта 5\% становлять зольні елементи (залишаються після спалювання рослин - калій, кальцій, магній, фосфор).

Однак окремі тканини і органи істотно відрізняються за вмістом золи. Так, зерно містить 3\% золи від маси сухої речовини, листя - 10-15\%, трав'янисті стебла і коріння - 4-5\%. Загальна кількість хімічних елементів, залучених у біологічний колообіг, i їх співвідношення багато в чому залежать від групи організмів (рослини, тварини, людина). Хімічний склад живих організмів визначає характер обміну речовин між організмом і середовищем. Один і той же хімічний елемент різні рослини утилізують в різних кількостях (табл. 3).

Таблиця 3 - Приблизний вміст деяких елементів в золі рослин, \%

\begin{tabular}{|c|c|c|c|c|c|}
\hline Культура & Продукція & $\mathrm{P}_{2} \mathrm{O}_{5}$ & $\mathrm{~K}_{2} \mathrm{O}$ & $\mathrm{CaO}$ & $\mathrm{MgO}$ \\
\hline \multirow{2}{*}{ Пшениця } & Зерно & 48 & 30 & 3 & 12 \\
\cline { 2 - 6 } & Солома & 10 & 30 & 20 & 6 \\
\hline \multirow{2}{*}{ Соняшник } & Насіння & 40 & 25 & 7 & 12 \\
\cline { 2 - 6 } & Стебло & 3 & 50 & 12 & 7 \\
\hline \multirow{2}{*}{ Горох } & Зерно & 30 & 40 & 5 & 6 \\
\cline { 2 - 6 } & Солома & 8 & 25 & 35 & 8 \\
\hline Гречка & Солома & 3 & 30 & 17 & 6 \\
\hline Жито & Солома & 5 & 12 & 9 & 4 \\
\hline
\end{tabular}

Після того, як посів буде зібрано, відходи сільського господарства (солому, стебла, лушпиння) збирають, відправляють на підприємство 3 виготовлення паливних брикетів та пелет, причому виробничі потужності з перероблення відходів необхідно розташовувати ближче до місця їх утворення. 


\section{Висновки}

1. Надходження важких металів 3 грунту в рослини на сьогоднішній день $\epsilon$ серйозною екологічною проблемою, внаслідок якої продукти харчування людини та тварин, а також відходи сільського господарства забруднюються важкими металами.

2. Переробка рослинних відходів в паливні брикети та пелети є досить ефективним екологічним рішенням, що дає змогу зв'язати важкі метали та запобігти їх міграції.

\section{СПИСОК ЛІТЕРАТУРИ}

1. П.Г. Кириенко, В.И. Калашникова, Е.Н. Варламов. Производство топливных брикетов из органических отходов. Экология и промышленность, №3, С. 87-90.

2. Пат. 98672 Україна, МПК (2006.01) C10L 5/44. Спосіб одержання паливного брикету / Кирієнко П.Г., Кобрін В.М., Нечипорук М.В., Мірсултанова Л.Р., Бюл. №11, від 11.06.2012 p.

3 Пат. 109598 Україна, МПК (2006.01) В30В 11/10, В27N 3/20. Пристрій для виготовлення брикетів / Кирієнко А.П., Кирієнко П.Г., Калашнікова В.І., Угрюмов М.Л., Бюл. №17, від 10.09.2015 р.

4. Г.А. Кроїк Токсикологічні аспекти накопичення та розподілу важких металів у грунтах промислових агломерацій. Біорізноманіття та роль тварин в екосистемах: Матеріали VI Міжнародної наукової конференції. - Дніпропетровськ: Вид-во ДНУ, 2011. - С. 15-18.

5. Методические указания по определению тяжелых металлов в почвах сельхозугодий, продукции растениеводства. М. 1992 г. С. 13-14.

6. Біоенергетика замість газу / Гелетуха Г., Желєзна Т. (Біоенергетична асоціація України). Економічна правда. [Електронний ресурс]. Джерело: http://www.epravda.com.ua/publications/2015/01/9/520368/.

Стаття надійшла до редакиії 02.04.2020 і прийнята до друку після рещензування 20.07.2020

\section{REFERENCES}

1. Kirienko, P.G., Kalashnikova, V.I., \& Varlamov, E.N. (2014). Production of fuel briquettes from organic waste. Ekologija i promyshlennost', 3, 87-90. (in Russian)

2. Kyrijenko, P.G., Kobrin, V.M., Nechyporuk, M.V., \& Mirsultanova, L.R. (2012). The method of obtaining fuel briquettes. Pat. 98672 Ukrai'na, MPK (2006.01) S10L 5/44. Bjul. №11, vid 11.06.2012 r. (in Ukrainian).

3. Kyrijenko, A.P., Kyrijenko, P.G., Kalashnikova, V.I., \& Ugrjumov, M.L. (2015). Device for making briquettes. Pat. 109598 Ukrai'na, MPK (2006.01) B30B 11/10, B27N 3/20. Bjul. №17, vid 10.09.2015 r. (in Ukrainian).

4. Kroi'k, G.A. (2011). Toxicological aspects of accumulation and distribution of heavy metals in soils of industrial agglomerations. Bioriznomanittja ta rol' tvaryn v ekosystemah: Materialy VI Mizhnarodnoi' naukovoi' konferencii (pp. 15-18). Dnipropetrovs'k: Vyd-vo DNU. (in Ukrainian).

5. Methodological guidelines for the determination of heavy metals in agricultural soils, crop production. (1992). Moskva. (in Russian)

6. Heletukha, H., \& Zheliezna, T. (Bioenergetychna asociacija Ukrai'ny). (2015). Bioenergy instead of gas. Ekonomichna pravda. Retrieved from: http://www.epravda.com.ua/ publications/2015/01/9/520368/. (in Ukrainian).

The article was received 02.04.2020 and was accepted after revision 20.07.2020 


\section{Киріснко Петро Григорович}

кандидат технічних наук, доцент кафедри хімії, екології та експертизних технологій Національного аерокосмічного університету ім. М.С. Жуковського «Харківський авіаційний інститут»

Адреса робоча: 61070 Україна, м. Харків, вул. Чкалова, 17

e-mail: p.kirienko@khai.edu

\section{Клочко Тетяна Олександрівна}

старший викладач, екологічний аудитор кафедри хімії, екології та експертизних технологій Національного аерокосмічного університету ім. М.Є. Жуковського «Харківський авіаційний інститут»

Адреса робоча: 61070 Україна, м. Харків, вул. Чкалова, 17

e-mail: t.klocko@khai.edu

\section{Хоменко Ірина Свгенівна}

провідний інженер кафедри хімії, екології та експертизних технологій Національного аерокосмічного університету ім. М.С. Жуковського «Харківський авіаційний інститут»

Адреса робоча: 61070 Україна, м. Харків, вул. Чкалова, 17

e-mail: khomenko.19.10@gmail.com

\section{Дурневич Ганна Михайлівна}

студентка кафедри хімії, екології та експертизних технологій Національного аерокосмічного університету ім. М.С. Жуковського «Харківський авіаційний інститут»

Адреса робоча: 61070 Україна, м. Харків, вул. Чкалова, 17

e-mail: anna.durnevich.99@gmail.com 